\title{
Assessing trophic relationships between shallow-water black corals (Antipatharia) and their symbionts using stable isotopes
}

\author{
Lucas Terrana $^{1, *}$, Gilles Lepoint ${ }^{2}$ \& Igor Eeckhaut $^{1}$ \\ ${ }^{1}$ Biology of Marine Organisms and Biomimetics, University of Mons, 7000 Mons, Belgium. \\ ${ }^{2}$ Laboratory of Oceanology-MARE Centre, University of Liège, 4000 Liège, Belgium. \\ *Corresponding author: lucas.terrana@umons.ac.be
}

\begin{abstract}
Shallow-water antipatharians host many symbiotic species, which spend their adult life with their host and/or use them to have access to food. Here we determine the trophic relationships between four common macrosymbionts observed on/in Cirripathes anguina, Cirrhipathes densiflora and Stichopathes maldivensis in SW Madagascar. These include the myzostomid Eenymeenymyzostoma nigrocorallium, the gobiid fish Bryaninops yongei, and two palaemonid shrimps, Pontonides unciger and Periclimenes sp. The first is an endosymbiont living in the digestive tract, while the others are ectosymbionts. The analyses show that most likely $(i)$ none of the symbionts uses the host as a main food source, (ii) nocturnal plankton represents a main part of the diet of antipatharians while the symbionts feed preferentially on diurnal plankton, (iii) the myzostomid has the narrowest trophic niche, (iv) the two shrimps have distinct trophic niches and feed at lower trophic level than do the other symbionts. Concerning the myzostomids, they had the same $\delta^{13} \mathrm{C}$ values but had significantly higher $\delta^{15} \mathrm{~N}$ values than the hosts. TEFs (Trophic Enrichment Factors) recorded were $\Delta^{13} \mathrm{C}=0.28 \pm 0.25 \%$ and $\Delta^{15} \mathrm{~N}=0.51 \pm 0.37 \%$, but these were not high enough to explain a predator-prey relationship. These worms rely on the coral diet but may also ingest host fluids explaining the slight enrichment in heavier nitrogen isotopes. On the other hand, the ectosymbionts use the coral as a pathway to have access to food from the midwater: they feed from the water passing nearby the black corals, but a kleptoparasitic behaviour cannot be excluded.
\end{abstract}

Keywords. Antipatharians, Black corals, Symbioses, Stable Isotopes, Madagascar.

Terrana L., Lepoint G. \& Eeckhaut I. (2019). Assessing trophic relationships between shallow-water black corals (Antipatharia) and their symbionts using stable isotopes. Belgian Journal of Zoology 149 (1): 107-121. https://doi.org/10.26496/bjz.2019.33

\section{Introduction}

Antipatharians, also called black corals, are found in diverse habitats, from shallow waters to abyssal plains. They are inhabited by numerous organisms such as worms, arthropods, cnidarians, bryozoans, molluscs, echinoderms and fishes (SOULE \& SOULE 1972; WIRTZ \& D'UDEKEM-D'ACOZ 2001; VEGA et al. 2002; KirKENDALE \& MESSING 2003; BOLAND \& PARRISH 2005; HeRler 2007; LOVE et al. 2007; Molodtsova \& BUdAeva 2007). This associated fauna takes advantage of the living or dead branches of their hosts as shelter or as nursery or feeding areas (BUHL-MORTENSEN \& MORTENSEN 2004; WAGNER et al. 2012). 
Amongst the black coral symbionts, decapods and gobiid fishes such as Bryaninops yongei (Davis \& Cohen, 1968) are commonly observed on their surface (see WAGNER et al. 2012 for a detailed exhaustive list of the symbionts). These symbionts never leave their host's branches and their social organisation and reproductive biology are well known: whip coral gobies from the genus Bryaninops are known to live in small groups of male-female pairs on their antipatharian or gorgonian hosts (LARSON 1985; MUNDAY et al. 2002). Shrimps are also commonly observed on black corals as well as on many other sessile organisms. In particular, members of the Pontoniidae family are well represented (DE RIDDER \& HolthUIS 1979; CRIALES 1980; MARIN 2007). They hide from predators thanks to the host colony morphology (WIRTZ \& D'UDEKEM D'ACOZ 2001). They are generally found living in heterosexual pairs, although larger groups may occur (BRUCE 2005; MARIN 2007). Recently, the myzostomid worm Eenymeenymyzostoma nigrocorallium Terrana \& Eeckhaut 2017 has been reported to live in the digestive tract of black corals (TERRANA \& EECKHAUT 2017). In general, myzostomids are associated with echinoderms, and particularly crinoids (see EECKHAUT \& LANTERBECQ 2005 for a review), but their presence as symbiotic organisms of black coral has already been briefly reported in the past (GoENAGA 1977; Bo et al. 2014).

The symbiotic fauna of black corals has generally been described based on direct observations of the behaviour or the presence of the symbiont on the corals. Feeding is one of the benefits of the relationship to the symbionts, with different ways for them to acquire their food. Boundaries between the different types of symbioses (e.g., parasitism, commensalism or mutualism) are not rigid and interactions are better illustrated as a large continuum (PARMENTIER \& MiCHEL 2013). In a general way, in a mutualistic relationship symbionts may remove encrusting fauna from the coral surface while feeding. In commensalism, the coral colony may act as an intermediary enabling symbionts to catch food from the water column (DAVIS \& COHEN 1968; SIH \& CHOUw 2009). Finally, in a parasitic association, the symbiotic organisms may directly feed on the host tissues or take food directly from off the coral polyps.

Observations made directly on black coral symbiont feeding habits are scarce and present the disadvantage of giving a snapshot and not a global view of their feeding behaviour. Moreover, long-term in situ observations are not always achievable in terms of technical support. On the other hand, carbon and nitrogen stable isotopes can give a global view of the feeding behaviour of organisms and have been used in the past as proxies to characterize symbiotic associations among marine organisms (e.g., CAULIER et al. 2014; TERRANA et al. 2016). Stable isotope ratios of carbon and nitrogen are powerful trophic markers, with the isotopic composition of the consumer tissues being directly linked to their diet (DENIRO \& EPSTEIN 1981). These values can be used to determine food source and trophic levels (POST 2002), and thus to assess the trophic relationships between symbiotic organisms. Proportions of the different food sources are reflected in the tissues of the predators, with enrichment in the heavier isotope (MCCUTCHAN et al. 2003). Parasites are considered by some authors as micro-predators (RAFFEL et al. 2008) that would be expected to be enriched in heavier isotopes (DOUCET et al. 1999). However, studies focusing on specific host-parasites relationships showed that they could be enriched and/or depleted in heavier isotopes compared with their hosts (IKEN et al. 2001; DEUDERO et al. 2002; PARMENTIER \& DAS 2004; POWER \& KLEIN 2004), particularly for nematodes and cestodes, which are known to be significantly depleted (IKEN et al. 2001; PINNEGAR et al. 2001).

To estimate the diet assimilated by consumers, several Bayesian mixing models have been developed (reviewed by PHILLIPS et al. 2014). In addition, it has been proposed that the variability of isotopic composition of a population or a species (i.e., its isotopic niche) can be used as a proxy to assess the trophic niche of this population or species, and/or the degree of individual specialization in the population (BEARHOP et al. 2004; JACKSON et al. 2011). This concept of isotopic niche has also been developed through diverse numerical methods (JACKSON et al. 2011). Comparison of isotopic niches allows an assessment of the variability and overlap of the diets among species. 
TERRANA L. et al., Trophic relationships between black corals and their symbionts

The aim of the present study was to use these tools to assess the trophic relationships of four macrosymbionts commonly found on three whip black corals hosts (Cirrhipathes anguina, Cirrhipathes densiflora and Stichopathes maldivensis) in the Southwest of Madagascar. The four symbionts are the gobiid fish Bryaninops yongei (Davis \& Cohen, 1969), the myzostomid Eenymeenymyzostoma nigrocorallium, and two palaemonid shrimps, Pontonides unciger Calman, 1939 and Periclimenes sp. The myzostomids live on the gastrovascular ducts of the black corals while the others are always found at their surface, but they all share the same hosts. Due to these behaviours, we try to answer these questions: (i) are the symbionts sharing the same trophic niches as their hosts and thus using the same food sources; or (ii) are they feeding on their hosts' tissues?

\section{Material and methods}

\section{Sampling}

All the samples were collected in November and December 2015 at the northern extremity of the Great Reef of Toliara in the Southwest of Madagascar $\left(23.36^{\circ} \mathrm{S}, 43.66^{\circ} \mathrm{E}\right)$ at a maximum depth of $25 \mathrm{~m}$. A total of 19 colonies belonging to three species of whip black corals were targeted for the collection of symbionts: Cirrhipathes anguina, Cirrhipathes densiflora and Stichopathes maldivensis. These corals are unbranched and can measure up to $5 \mathrm{~m}$ in length. Their surfaces were examined in situ and three ectosymbiotic species were consequently sampled: the gobiid fishes Bryaninops yongei $(n=14)$ and the shrimps Pontonides unciger $(n=11)$ and Periclimenes sp. $(n=7)$. For the identification of the last species, the collected shrimps Periclimenes sp. were compared to all the shrimp species associated with antipatharians listed in the exhaustive table of WAGNER et al. (2012) and to all the symbiotic shrimps recorded in Madagascar by BRUCE (1978). However, the present specimens did not match any species description as their rostrum was smooth, very sharp and slightly curved downwards.

All the ectosymbiotic specimens were collected by putting a sealable zipper storage bag at the apex of the black coral colonies before forcing them to move towards it. Tissues of the black corals were then collected by cutting a fragment of $15 \mathrm{~cm}$ in the distal part. The collection of the distal fragment also allowed a search for the presence of endosymbionts, leading to the collection of 82 specimens of the myzostomid Eenymeenymyzostoma nigrocorallium found in the gastrovascular cavities of the black corals.

After their capture, all the fishes were euthanized as quickly as possible with an overdose of MS222 (tricaine-methanosulfonate). Muscles from their lateral side were dissected for analysis. For the myzostomids, it was not possible to isolate or remove the digestive apparatus because it is reticulated and spread all over the body (TERRANA \& EECKHAUT 2017). Due to their minute sizes, all the shrimps were analysed whole as well.

Potential food sources were sampled by collecting surface mesozooplankton during the night and the day with a $100 \mu \mathrm{m}$ net dragged for $15 \min (n=10$ for the night, $n=10$ for the day). Stable isotope ratios of nocturnal benthic copepod from FRÉDÉRICH et al. (2017) were used as they were from the same collection sites in the same period. These copepods were trapped using small light traps made by plastic bottles containing glow sticks. Sample treatment and analysis were the same as applied here.

\section{Stable isotope analysis}

All samples were dried at $60^{\circ} \mathrm{C}$ for at least 72 hours. They were ground into a homogenous powder using a mortar and pestle. Each sample of shrimp and plankton was subdivided into two parts, of which one was exposed to fuming $\mathrm{HCl}(37 \%)$ during 24 to 48 hours in order to remove the carbonates and then re-dried. The acidified samples were used for carbon stable isotope analysis, while the non-acidified samples were used for nitrogen stable isotope analysis. 
Each sample was analysed using a mass spectrometer (Isoprime 100, Isoprime, UK) fitted with an elemental analyser (VarioMicro, Elementar, Germany) for combustion and automated analysis. Carbon and nitrogen isotope ratios were expressed as $\delta$ values (\%o) using ammonium sulfate IAEA-N1 $\left(\delta^{15} \mathrm{~N}=0.4 \pm 0.2 \%\right.$; mean $\left.\pm \mathrm{SD}\right)$ and sucrose IAEA-C6 $\left(\delta^{13} \mathrm{C}=-10.8 \pm 0.5 \%\right.$; mean $\left.\pm \mathrm{SD}\right)$ as certified reference materials for nitrogen and carbon respectively. These references are both calibrated against the international isotopic references Vienna Pee Dee Belemnite for carbon and atmospheric air for nitrogen. Standard deviations on multibatch replicate measurements of one black coral sample were $\pm 0.2 \%$ for carbon and $\pm 0.1 \%$ for nitrogen.

\section{Data treatment and statistics}

Because all the symbionts could be found on each black coral species, the latter were considered as a single group for stable isotope analysis. Only the associations between black corals -regardless of the species- and the myzostomids were also considered specifically in order to evaluate the enrichment in heavy isotopes between a host and its symbionts (see below).

Means of the isotope ratio values were plotted with their standard deviations. Using each individual measurement, the SIBER package ver. 2.0 (Stable Isotope Bayesian Ellipses in R) was used to assess the isotopic niche parameters in R software (JACKSON et al. 2011; R DEVELOPMENT CORE TEAM 2015). The model generates bivariate standard ellipses whose areas (SEA) represent the core isotopic niche, which contains $40 \%$ of the data (JACKSON et al. 2011), as it does not encompass outlier individuals in the isotopic space. When dealing with sample sizes less than 30 individuals, a correction for small sample size can be used (SEA, SYVÄRANTA et al. 2013). This is an effective way to compare small and/or unbalanced samples, and it tends to converge when sample size increases (JACKSON et al. 2011). Areas of the ellipses associated to each population were also estimated using Bayesian modelling (SEA ${ }_{B}$; $10^{5}$ iterations). SEA $\mathrm{B}_{\mathrm{B}}$ involves the use of an iterative model based on Bayesian inference to estimate the covariance matrix from the data. $\mathrm{SEA}_{\mathrm{B}}$ considers variability (caused by both natural variations and analytical error) more efficiently and provides a distribution of solutions rather than a single value, thereby allowing error estimates as well as pairwise comparisons. Model solutions were presented using credibility intervals of probability density function distributions. Direct pairwise comparisons were performed and were considered meaningful when probability of occurrence (i.e., number of model solution) exceeded $95 \%$.

Community-wide Layman's metrics were also calculated for each group. These metrics include 6 parameters used as descriptors of the trophic niches: (i) the $\delta^{13} \mathrm{C}$ range $(\mathrm{CR})$ which is greater when multiple resources support the consumers; (ii) the $\delta^{15} \mathrm{~N}$ range (NR) which is greater when consumers belong to several trophic levels; (iii) the total area of the convex hull (TA) representing the overall trophic diversity; (iv) the mean distance to centroid (CD) which is an averaged measure of trophic diversity among consumers; (v) the mean nearest-neighbour distance (NND) indicative of the trophic redundancy; and (vi) the standard deviation of the NND (SDNND) indicative of how evenly trophic diversity is distributed among the group.

The trophic enrichment factor, which is the enrichment or the depletion in heavier isotopes from prey to predator $\left(\Delta^{15} \mathrm{~N}\right.$ and $\left.\Delta^{13} \mathrm{C}\right)$ was calculated for myzostomids and their black coral hosts. It was based on the hypothesis that the association is driven by a predator-prey relationship as expected for endoparasitic species (DOUCETT et al. 1999; RAFFEL et al. 2008). All the 82 myzostomids were found in 10 out of the 19 black coral fragments belonging to the three previously named species. Only one antipatharian fragment showed a single myzostomid, while the other fragments were inhabited by a maximum of two to 20 myzostomids. For each symbiotic association, i.e., a group of myzostomids and the black coral they inhabit, the value of both nitrogen and carbon stable isotope composition of the host was compared to the mean values of the respective group of symbionts. 
TERRANA L. et al., Trophic relationships between black corals and their symbionts

The stable isotope-mixing model SIAR (PARNELL et al. 2008) was used to estimate the relative contribution of the different food sources collected to the diet of the symbionts. Isotopic compositions of the four symbionts species and means and standard deviations of the different potential food sources (i.e., day and night zooplankton, nocturnal benthic copepods and black coral tissues) were fitted in R. A concentration-dependent mixing model was used following a Kruskal-Wallis test on C:N ratios of each food source. This model was chosen because the standard model assumes that the proportional contribution of a source to a mixture is the same for both carbon and nitrogen elements. However, in the case where one or several sources are richer or poorer in one element, there is a proportional increase or decrease in the contribution of that source to the mixture relative to the other element. The concentrationdependent mixing model assumes that for each element, a source's contribution is proportional to the contributed mass times the elemental concentration in that source (PHILLIPS \& KOCH 2002).

Trophic enrichment factors (TEF) for marine organisms obtained from MCCUTCHAN et al. (2003) were implemented in the mixing model. Solutions are presented using credibility intervals of probability density function distributions.

\section{Results}

\section{Stable isotope compositions and trophic niches}

Values of $\delta^{15} \mathrm{~N}$ differed significantly among organisms (Fig. 1a, ANOVA, $F=349.16, d f=8, \mathrm{P}<0.001$ ). The myzostomids Eenymeenymyzostoma nigrocorallium and the fishes Bryaninops yongei had higher mean $\delta^{15} \mathrm{~N}$ values than the black corals (Fig. 1a, Table 1) which were significantly different (Tukey $\mathrm{P}<0.05$ ). By contrast, both shrimp species had significantly lower values than the black corals (Fig. 1a, Table 1, Tukey $\mathrm{P}<0.05)$. The fishes and the myzostomids did not show significant differences between their mean $\delta^{15} \mathrm{~N}$ values (Fig. 1a, Table 1, Tukey $\mathrm{P}>0.99$ ). Black corals and their symbionts did not exhibit significant differences in $\delta^{13} \mathrm{C}$ values (Fig. 1a, Table 1, Tukey $\mathrm{P}>0.05$ ). Regarding the sources, mesozooplankton collected during the day displayed significant differences in $\delta^{13} \mathrm{C}$ values compared with black corals and their symbionts, except for Periclimenes sp. (Tukey, $\mathrm{P}=0.77$ ). Mesozooplankton collected during the night exhibited significantly different $\delta^{13} \mathrm{C}$ values compared with the black corals and the symbionts, except for Periclimenes sp. and B. yongei (Tukey, $\mathrm{P}=0.947$ and $\mathrm{P}=0.056$ respectively). Zoobenthos differed always significantly $(\mathrm{p}<0.001)$ from all symbionts and corals.

Isotopic niche area of corals and their symbionts ranged from $0.21 \% 0^{2}$ to $0.62 \%^{2}\left(\mathrm{SEA}_{\mathrm{C}}\right.$, Table 2 ). The niche widths of the different samples were variable as shown with pairwise comparisons of the Bayesian model-estimated ellipse areas ( $\mathrm{SEA}_{\mathrm{B}}$, Table 3). Amongst all species, the myzostomids E. nigrocorallium had always the smallest isotopic niche width (Fig. 2, Tables 2-3). Despite having the smallest SEAc (Fig. 1b, Tables 2-3), myzostomids showed the largest nitrogen and carbon ranges, as well as the largest convex hull as shown by the community-wide Layman's metrics (Table 2). They had the highest trophic redundancy with the lowest mean neighbour-nearest distance (Table 2). In comparison, black corals and the fishes presented close values for their convex hulls, which were lower than those of myzostomids (Table 2). The fishes showed the highest distance from the centroid, while myzostomids showed the lowest distance. The two species of shrimp had similar Layman's metrics, except for the SEAc of Periclimenes sp. which was two times higher than that of Pontonides unciger (Table 2).

The bivariate standard ellipses (corrected for sample sizes) of the black corals overlapped those of the fishes and the myzostomids, but not those of both shrimps (Fig. 1b, Table 4). The niche overlap was the highest between the myzostomids and the fishes, while it was the lowest between the black corals and the myzostomids (Table 4). The myzostomids trophic niche was mostly comprised within the trophic niche of the fishes, with $95.23 \%$ of the ellipse covered (Fig. 1b, Table 4). 
When considering each black coral and its respective myzostomids, the myzostomids were always enriched in $\delta^{13} \mathrm{C}$ (mean $\Delta^{13} \mathrm{C}=0.28 \pm 0.25 \%$ ) while in nine out of 10 cases they were enriched in $\delta^{15} \mathrm{~N}$ (mean $\Delta^{15} \mathrm{~N}=0.51 \pm 0.37 \%$ ) with respect to their host (Fig. 3).
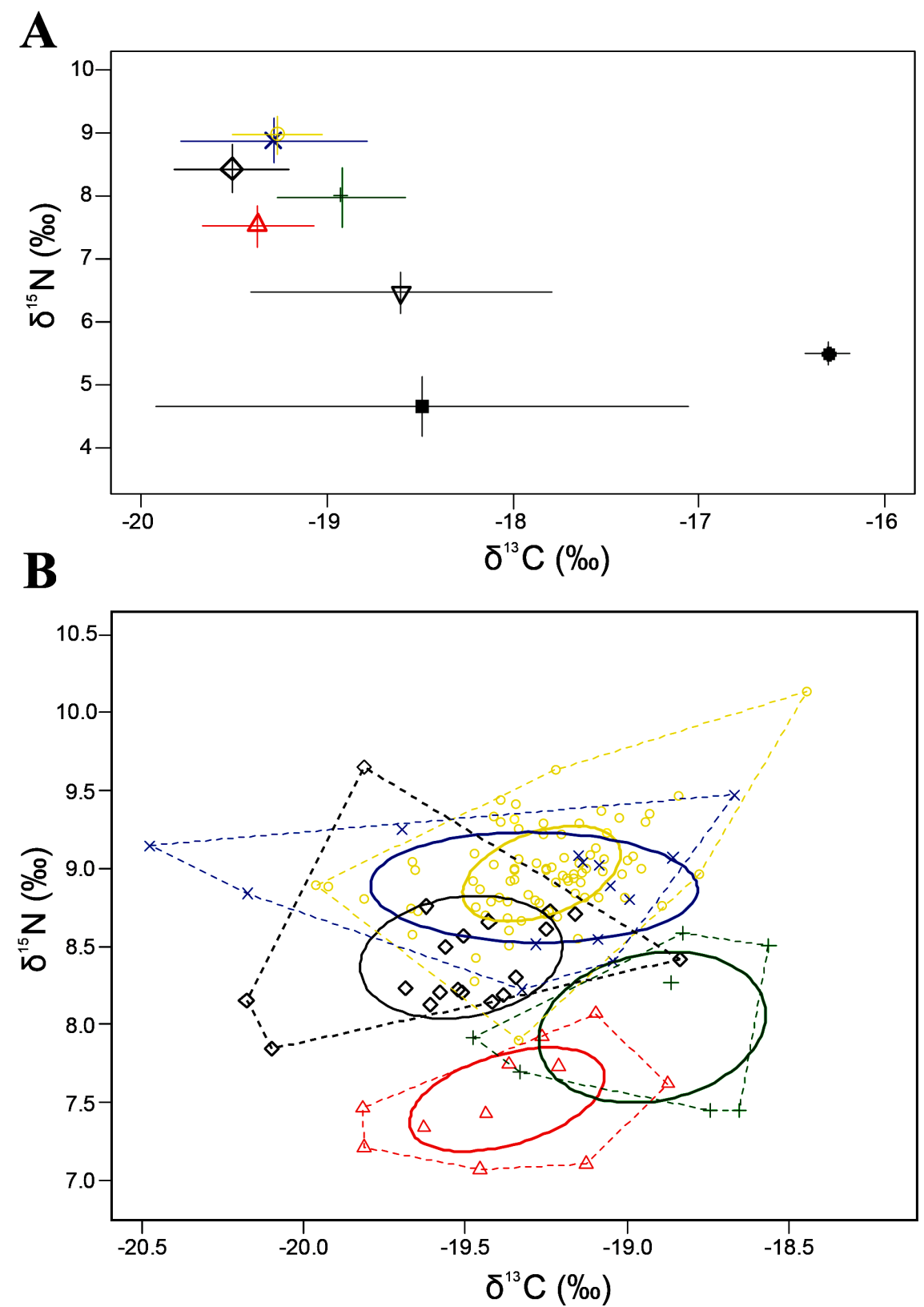

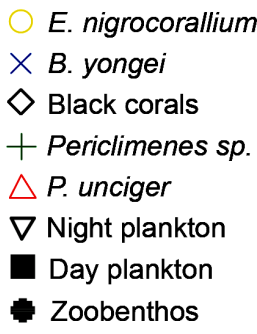

E. nigrocorallium + Periclimenes sp. $\triangle P$. unciger $\nabla$ Night plankton

- Zoobenthos

Fig. 1 - A. Mean values $( \pm \mathrm{SD})$ of $\delta^{13} \mathrm{C}(\%)$ and $\delta^{15} \mathrm{~N}(\%)$ of the symbionts and potential food sources. There is no difference in trophic level among the black corals and their associated fauna. B. Isotopic niches of the symbionts and the black coral hosts represented by the convex hull in dashed lines. The core isotopic niche of each group is represented by the standard ellipse area corrected for sample sizes $\left(\% 0^{2}\right)$ of each group. The ellipses of the shrimps do not overlap at all with those of the hosts. In contrast, overlaps exist between the ellipses of the black corals, the myzostomid worms and the gobiid fishes, meaning that they share a part of the same isotopic niche. 
TERRANA L. et al., Trophic relationships between black corals and their symbionts

TABLE 1

Mean, minimum and maximum values (\%) of $\delta^{13} \mathrm{C}$ and $\delta^{15} \mathrm{~N}$ for the coral hosts, the symbionts and the potential food sources.

\begin{tabular}{|c|c|c|c|c|c|c|}
\hline \multirow{2}{*}{ Organism } & \multicolumn{3}{|c|}{$\delta 13 \mathrm{C}(\%)$} & \multicolumn{3}{|c|}{ 815N (\%o) } \\
\hline & Mean & Min & Max & Mean & Min & Max \\
\hline Black corals & -19.5 & -20.2 & -18.8 & 8.4 & 7.8 & 9.6 \\
\hline Eenymeenymyzostoma nigrocorallium & -19.3 & -20.0 & -18.4 & 9.0 & 7.9 & 10.1 \\
\hline Bryaninops yongeii & -19.3 & -20.5 & -18.7 & 8.9 & 8.2 & 9.5 \\
\hline Pontonides unciger & -19.4 & -19.8 & -18.9 & 7.5 & 7.0 & 8.1 \\
\hline Periclimenes sp. & -18.9 & -19.5 & -18.6 & 8.0 & 7.4 & 8.6 \\
\hline Night zooplankton & -18.6 & -19.1 & -16.4 & 6.5 & 5.7 & 7.0 \\
\hline Day zooplankton & -18.5 & -22.4 & -17.3 & 4.7 & 4.1 & 5.6 \\
\hline
\end{tabular}

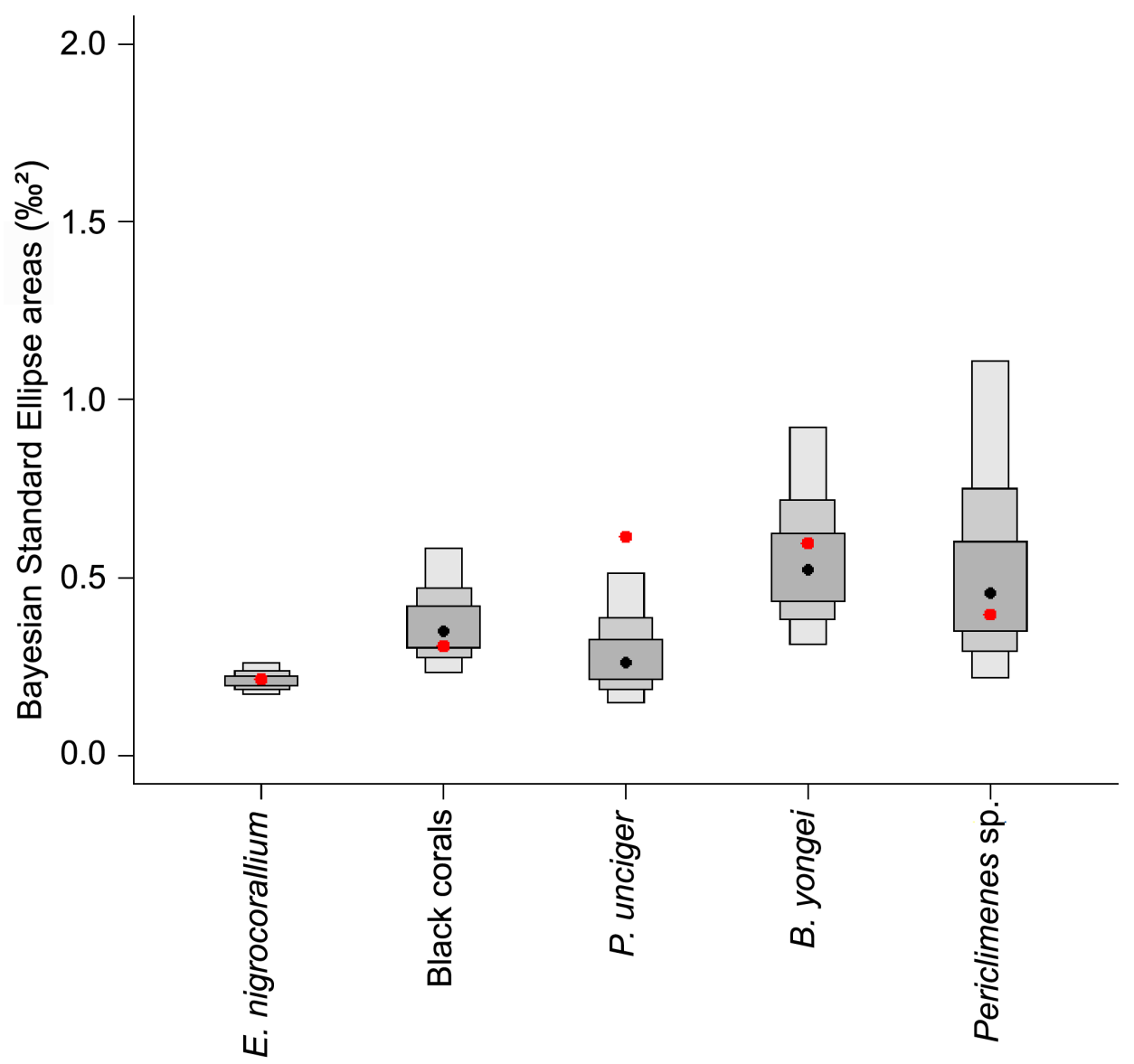

Fig. 2 - Estimates of standard ellipse area (SEA) for each species. The boxplots represent posterior probability distributions of model estimations of the standard ellipse areas $\left(\mathrm{SEA}_{\mathrm{B}}\right)$. The boxes are the $50 \%, 75 \%$ and $95 \%$ credibility interval. The mode of each distribution is shown by a black dot, while the red dot represents the standard ellipse area calculated using correction for small sample size $\left(\mathrm{SEA}_{\mathrm{C}}\right)$. The shrimps have the largest SEA meaning a higher variability in the stable isotope compositions, while the myzostomid worms have the smaller niche, meaning a very low variability in their stable isotope compositions. 


\section{TABLE 2}

Layman's community wide metrics for each group. $\mathrm{NR}=$ nitrogen range, $\mathrm{CR}=$ carbon range, $\mathrm{CD}=$ distance from the centroid, NND = nearest-neighbor distance, SDNND = standard deviation of the $\mathrm{NND}, \mathrm{TA}=$ total area of the convex hull $\left(\% \mathrm{o}^{2}\right), \mathrm{SEAc}=$ standard ellipse area corrected for sample size $\left(\% 0^{2}\right)$.

\begin{tabular}{lccccccc}
\hline \multicolumn{1}{c}{ Organism } & NR & CR & CD & NND & SDNND & TA & SEAc \\
\hline Black corals & 1.80 & 1.34 & 0.40 & 0.17 & 0.21 & 1.18 & 0.39 \\
E. nigrocorallium & 2.23 & 1.88 & 0.32 & 0.08 & 0.12 & 2.13 & 0.21 \\
B. yongeii & 1.25 & 1.81 & 0.51 & 0.23 & 0.17 & 1.17 & 0.59 \\
P. unciger & 1.00 & 0.94 & 0.40 & 0.24 & 0.07 & 0.57 & 0.31 \\
Periclimenes sp. & 1.14 & 0.91 & 0.54 & 0.23 & 0.09 & 0.64 & 0.62 \\
\hline
\end{tabular}

\section{TABLE 3}

Pairwise comparisons of the areas of standard ellipses estimated using Bayesian modelling $\left(\mathrm{SEA}_{\mathrm{B}}\right)$. The relative probabilities (\%) that the standard ellipse of the group listed as line is smaller than the standard ellipse of the group listed as column are shown. Probabilities are based on $10^{5}$ iterations. Values with an asterisk are probabilities higher than $95 \%$.

\begin{tabular}{lccccc}
\hline & B. yongei & Black corals & E.nigrocorallium & Periclimenes & P. unciger \\
\hline B. yongei & - & 0.129 & $<0.001$ & 0.469 & 0.057 \\
Black corals & 0.871 & - & 0.007 & 0.792 & 0.251 \\
E.nigrocorallium & $0.999^{*}$ & $0.992^{*}$ & - & $0.99^{*}$ & 0.848 \\
Periclimenes & 0.53 & 0.207 & 0.003 & - & 0.098 \\
P. unciger & 0.942 & 0.749 & 0.151 & 0.901 & - \\
\hline
\end{tabular}
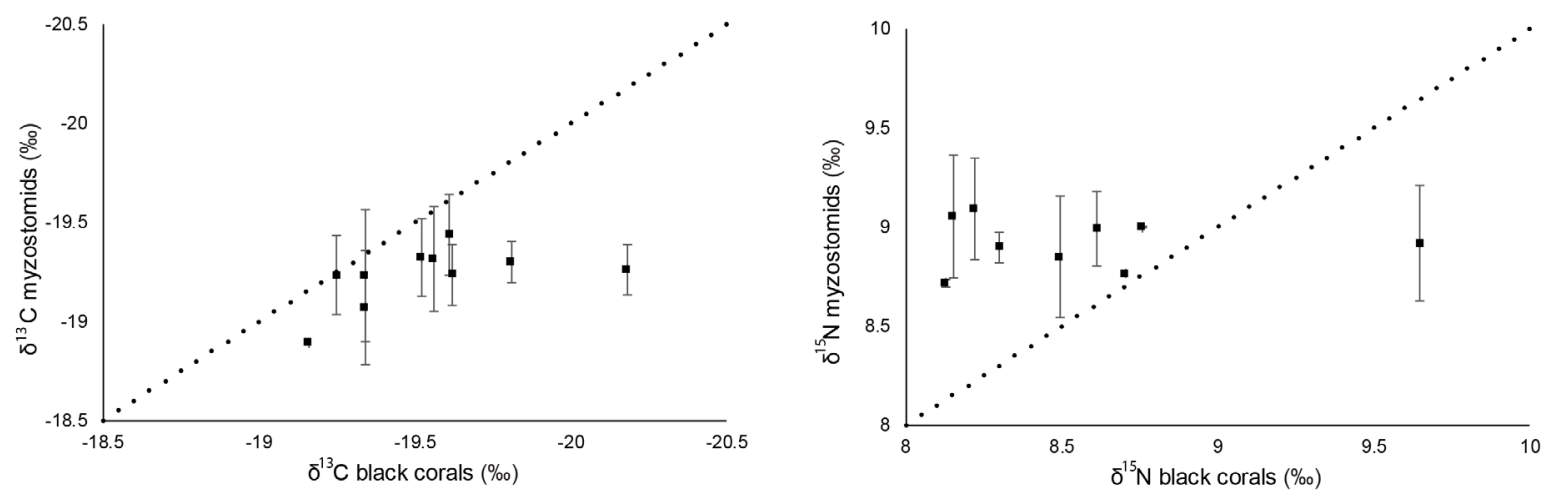

Fig. 3 - Stable carbon and nitrogen isotope data for Eenymeenymyzostoma nigrocorallium vs their respective black coral hosts. The dashed line represents a 1:1 linear relationship. Standard deviations were calculated depending on the (varied) number of worms found on each host. The endosymbiotic myzostomid worms are enriched in both stable isotopes $\mathrm{C}$ and $\mathrm{N}$ when compared to their coral hosts. 
TERRANA L. et al., Trophic relationships between black corals and their symbionts

TABLE 4

Values of the core isotopic niche overlaps between the species with their respective surfaces covered.

\begin{tabular}{|c|c|c|c|c|}
\hline \multicolumn{2}{|c|}{ Overlap between } & \multirow{2}{*}{\begin{tabular}{|c} 
Total niche overlap \\
$\left(\%^{2}\right)$
\end{tabular}} & \multicolumn{2}{|c|}{ Surface of the niche overlapped (\%) } \\
\hline Species 1 & Species 2 & & Species 1 & Species 2 \\
\hline Black corals & B. yongei & 0.11 & 28.2 & 18.64 \\
\hline Black corals & E. nigrocorallium & 0.03 & 7.69 & 14.28 \\
\hline E. nigrocorallium & B. yongei & 0.2 & 95.23 & 33.89 \\
\hline P. unciger & Periclimenes sp. & 0.06 & 19.35 & 9.83 \\
\hline
\end{tabular}

\section{Mixing model and resources uses}

The C:N ratios of each food source were significantly different $\left(X^{2}=30.458, \mathrm{p}<0.001\right)$, consequently a concentration-dependent mixing model was used in SIAR. The estimated relative contribution of each of the potential food sources varied among the symbionts as shown by the mixing model (Fig. 4) using TEFs from MCCUTCHAN et al. (2003). Overall, black coral tissues constituted a relatively small proportion of the symbionts' diets (Table 5). They were mostly represented within the myzostomids, whereas they were less represented in both shrimp species (Fig. 4, Table 5). Mesozooplankton collected during the day was the most used resource estimated by the mixing model, with ranges of $46-85 \%$
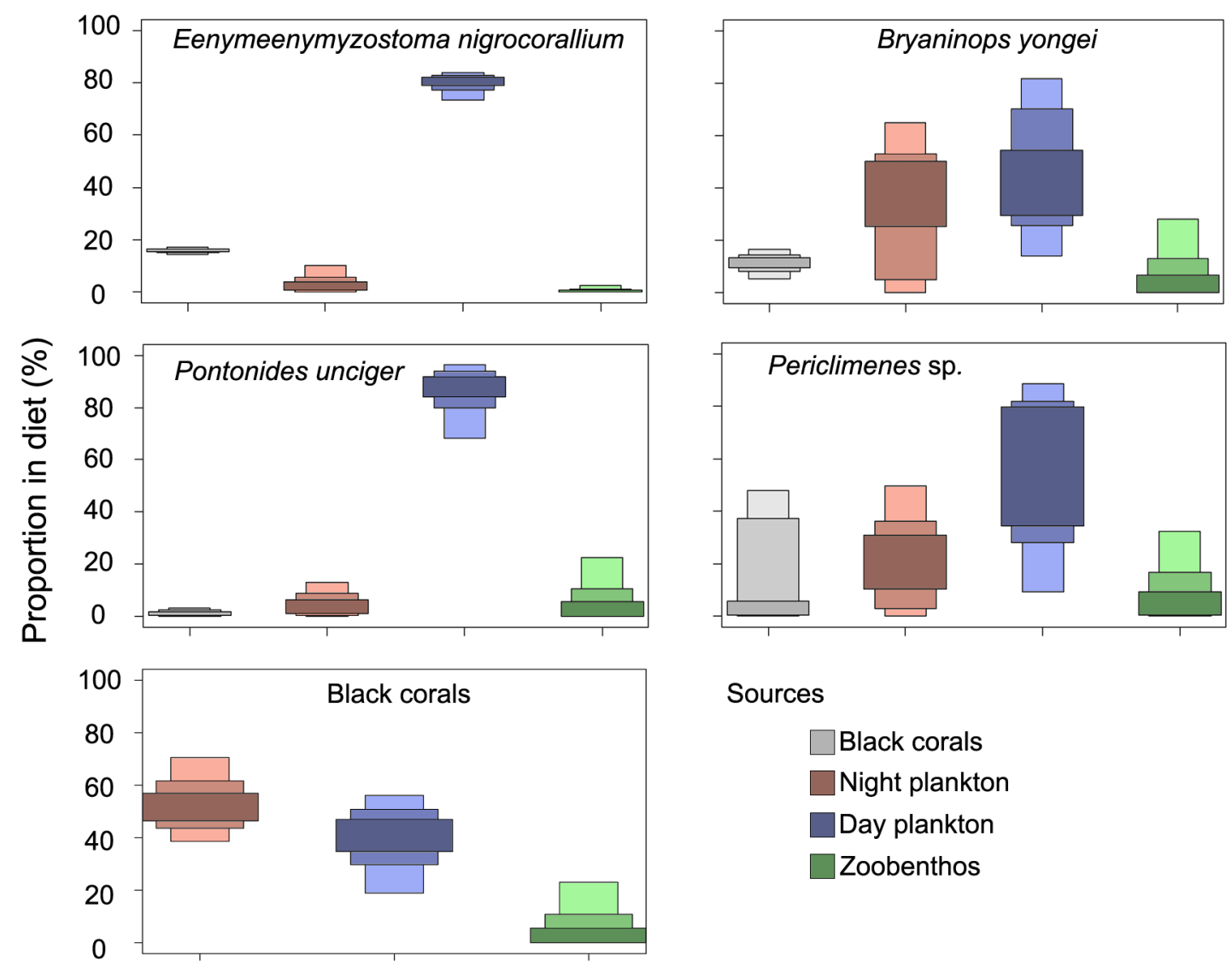

Sources

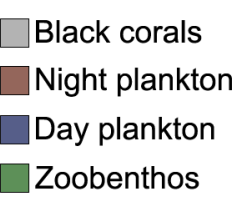

Fig. 4 - Boxplots of the relative contributions of the different potential food sources to the diet of the symbionts and the black corals. Credibility intervals $(\mathrm{CI}): \mathrm{CI}_{50}=$ dark colour, $\mathrm{CI}_{75}=$ medium colour, $\mathrm{CI}_{95}=$ light colour. Grey = black corals; red = night plankton; blue = day plankton; green = zoobenthos. 


\section{TABLE 5}

Contribution of each tested food source to the diet of the four symbionts (\%) as modelled by SIAR. The credibility intervals for $95 \%$ are given (CI 95).

\begin{tabular}{lcc|cc|cc|cc|cc}
\hline & \multicolumn{2}{c|}{ E. nigrocorallium } & \multicolumn{2}{c|}{ P. unciger } & \multicolumn{2}{c|}{ Periclimenes sp. } & \multicolumn{2}{c}{ B. yongei } & \multicolumn{2}{c}{ Black corals } \\
& Mode & CI 95 & Mode & CI 95 & Mode & CI 95 & Mode & CI 95 & Mode & CI 95 \\
\hline Black corals & 15.81 & $14.49-17.17$ & 0.98 & $0-3.40$ & 2.77 & $0-47.81$ & 11.96 & $5.46-16.56$ & - & - \\
Night & 2.66 & $0-10.29$ & 4.69 & $0-12.69$ & 20.64 & $0-49.47$ & 39.2 & $0-63.73$ & 52.66 & $38.23-70.49$ \\
Plankton & & & & & & & & & & \\
Day Plankton & 79.75 & $73.26-83.77$ & 87.54 & $70.37-96.40$ & 72.69 & $9.68-89.09$ & 42.03 & $15.29-82.35$ & 41.65 & $18.13-56.02$ \\
Zoobenthos & 0.2 & $0-2.37$ & 1.88 & $0-22.20$ & 2.63 & $0-32.33$ & 1.84 & $0-27.00$ & 1.58 & $0-23.14$ \\
\hline
\end{tabular}

(Fig. 4, Table 5). In contrast, zoobenthos was the least represented in the diet of all the symbionts, with an almost non-existent contribution in the myzostomid diet (range $0.01 \%-9.21 \%$ for all the symbionts, Fig. 4, Table 5). Night plankton was the most abundant food source for black corals as consumers, along with day plankton (Fig. 4, Table 5).

\section{Discussion}

The analyses show that most likely none of the symbionts uses the host as a main food source, but rather they rely mainly on diurnal plankton. Therefore, the ectosymbionts would use the corals as a pathway to have access to the food source from the midwater passing nearby the black corals. However, a kleptoparasitic behaviour cannot be excluded, highlighting that the different kind of symbioses may represent a continuum between commensalism and parasitism. On the other hand, the endosymbiotic myzostomids living in the gastrovascular ducts of their host rely on them to have access to food. The trophic enrichment factors recorded were not high enough to explain a predator-prey relationship. Therefore, the slight enrichment in heavier nitrogen isotopes might be related to the ingestion of host fluids along with prey processed or not by the antipatharians.

Black corals and their symbionts exhibited $\delta^{13} \mathrm{C}$ values that were consistent with organisms relying on planktonic resources (FRÉDÉRICH et al. 2017). The different values obtained for $\delta^{15} \mathrm{~N}$ showed segregation into different trophic levels, with day plankton lowest and the fishes and myzostomids highest. The difference between the two latter species and the black corals was not high enough to discriminate between two different trophic levels when considering the general value of $2.3 \%$ as a trophic level shift (MCCUTCHAN et al. 2003). Both shrimp species exhibited a lower trophic level compared to the group encompassing black corals, myzostomids and fishes. These results show that none of these species rely on the surrounding zoobenthos but rather are dependent on food from the water column.

Analysis of the ellipses, i.e., the trophic niches, confirmed that there was a clear segregation between the shrimps and the rest of the symbiotic assemblage composed of black corals, myzostomids and fishes. The two shrimps and the fishes showed the largest isotopic niches, which would indicate that these organisms have a more diversified diet than their hosts and the myzostomids. However, it is most likely that the shrimp data present such large ellipses because of the small sample size, and this is supported by their Layman's metrics as they show the smallest convex hull area and carbon and nitrogen ranges. These parameters are representative of small overall trophic diversities in both shrimp species, and the mixing model suggests that they mainly feed on prey coming from the diurnal plankton. The non-existent overlap between ellipses from P. unciger and Pontonides sp. and their antipatharian hosts suggests that the type of prey are totally different. 
TERRANA L. et al., Trophic relationships between black corals and their symbionts

On the other hand, the large trophic niches of the gobiid fishes likely represent an increased diversity of their food sources, as supported by the Layman's metrics indicating the use of different food sources and an increased overall trophic diversity between the individuals. These larger niches may be related to increased foraging capacities due to their ability to swim and change between hosts, leading to an increase in population niche width (DARIMONT et al. 2009; SEMMENS et al. 2009; RICHOUX \& NDHLOVU 2015). This is especially the case for the symbionts studied here as they were collected in an area where whip black corals are abundant and numerous, forming a black coral bed. An increased isotopic variance may also be linked to organisms feeding from different trophic levels (BEARHOP et al. 2004; RichOUX \& NDHLOVU 2015). The mixing model shows that both nocturnal and diurnal plankton are the main resource used by the fishes. As a result, the wide isotopic range of the fishes is representative of the variability in both diurnal and nocturnal plankton seen in this case. In addition, behavioral and morphological observations support a diet based on these resources: they have a large mouth and teeth linked to a carnivorous diet (DAVIS \& COHEN 1968; MUNDAY et al. 2002), while LARSON (1985) and DAVIS \& COHEN (1968) observed these fishes darting from the coral hosts to prey on small zooplankton passing nearby. Consequently, they certainly take advantage of the whip coral height to have direct and easy access to the plankton. Still, black corals contribute to a certain extent to the diet of the fishes based on the mixing model. This can be interpreted by several hypotheses: (i) mucus from the host could be directly used by the symbionts as one of their food sources, (ii) mucus could be indirectly ingested when the symbionts are capturing their prey and feeding at the surface of the corals, (iii) the symbionts could be kleptoparasites and steal prey captured by the coral polyps, or (iv) all these hypotheses simultaneously. In this case, stable isotope analyses are unable to discriminate between these different feeding behaviors, and direct observations are needed to confirm one or several hypotheses.

In contrast to the corals or the three other symbiont species, the myzostomid E. nigrocorallium has the lowest trophic niche area, which would mean that they are the most restricted in terms of food sources. This is represented by both the small ellipse and the small NND and SDNND parameters in Layman's metrics, also indicating an even trophic diversity among the group. These organisms are found freely moving in the digestive tracts of their host (TERRANA \& EECKHAUT 2017), consequently they are not restricted to feeding on specific host tissues. Two types of food sources are available for them: either they are foraging in the coral ducts and feed on the prey captured by the host and use them as food already processed by the coral or not; or they feed on their host's tissues, partially or not. If they were directly using freshly captured and unprocessed prey from their host, similar Layman's metrics and large overlaps between the trophic niches from the antipatharians and the symbionts would be expected, but it was not observed in this case where the niche overlap was small and only represented around $7 \%{ }^{2}$ of the niche of the antipatharians. When they feed on their host tissues, parasites are sometimes considered as micropredators (RAFFEL et al. 2008) and are expected to be enriched in $\mathrm{N}$ or C with respect to their hosts, similarly to a macropredator (DOUCETT et al. 1999). However, some studies have shown that both enriched and depleted isotopic compositions occur in parasites (BOAG et al. 1998; NEILSON \& BROWN 1999; BAILLON et al. 2014). For instance, endoparasitic nematodes and cestodes in fishes are often depleted in $\delta^{15} \mathrm{~N}$ compared to their host, especially among those that are devoid of digestive tracts (IKEN et al. 2001; PINNEGAR et al. 2001), while among ectoparasites stable isotopes ratios may depend on their feeding strategy and/or life-history stage (IKEN et al. 2001; PINNEGAR et al. 2001). Host-parasite trophic studies that have focused on cnidarian hosts of endoparasites (BAILLON et al. 2014; FLEMING et al. 2014) or endoparasitic polychaetes (BECKER et al. 2013) have unveiled different trophic enrichment factors ranging from $-2.0 \%$ to $+1.08 \%$ for $\delta^{13} \mathrm{C}$ and $-1.0 \%$ to $+2.62 \%$ o for $\delta^{15} \mathrm{~N}$. In the present work, myzostomids were enriched in both $\delta^{13} \mathrm{C}$ and $\delta^{15} \mathrm{~N}$ with respect to the black corals but the calculated enrichment factors were low $(\Delta 13 \mathrm{C}=0.28 \pm 0.25 \% 0$ and $\Delta 15 \mathrm{~N}=0.51 \pm 0.37 \%$ ). These values do not correspond to the expected increase in trophic level for predators as exposed by MCCUTCHAN et al. (2003). Accordingly, these results combined with the mixing model and the behavior of the myzostomids suggest that most likely E. nigrocorallium uses the food circulating in the host digestive tract. Therefore, the TEFs observed here with a slight enrichment in $\delta^{15} \mathrm{~N}$ and $\delta^{13} \mathrm{C}$ with respect 
to the corals might be explained by a limited consumption of the host digestive fluids or mucus, although the composition of the latter remains unknown. The high nitrogen and carbon ranges as well as the convex hull area observed for the myzostomids also support the interpretation that they may reflect the variability of their hosts, which are themselves showing high diversity between consumers and low consistency in the trophic diversity by feeding on planktonic resources displaying large variabilities. Feeding strategy appears to be similar among other species within the Myzostomida. The endosymbiotic genera Asteriomyzostomum and Notopharyngoides living in the digestive lumen of their hosts (asteroids and crinoids, respectively) steal particles ingested by their host, in the same way as E. nigrocorallium could do (EECKHAUT \& LANTERBECQ 2005). Myzostomida also include ectosymbiotic species that move freely at the surface of crinoids or induce cysts on their hosts. They are known to feed on particles captured by their introvert (EECKHAUT \& LANTERBECQ 2005). In a previous study, $\delta^{15} \mathrm{~N}$ and $\delta^{13} \mathrm{C}$ values of the ectosymbiont Myzostoma fissum and its crinoid host L. palmata indicated that the host and the symbiont shared the same food source (CAULIER et al. 2014), both organisms being suspension feeders.

In conclusion, our results along with observations retrieved from literature support the hypothesis that none of the symbionts directly uses its host tissues as a primary resource. This is also supported by direct observations of the corals, where no evident lack of tissue or scars are seen in situ. It is also important to keep in mind that trophic enrichment factors retrieved from literature are commonly used but do not always depict the way consumers are enriched in heavier isotopes compared to their food sources. In such cases, the use of standard ellipses and Layman's community-wide metrics are more reliable tools to interpret trophic relationships between organisms. Finally, hosting all these symbionts may either be favorable for the black corals, as symbionts could remove parasites or keep away predators even by ingesting coral mucus as a consequence of their feeding behavior, or they could behave as kleptoparasites by stealing prey captured by the coral polyps. These examples point out the importance of bringing together behavioral observations with stable isotope studies to unveil the nature of the associations among organisms.

\section{Acknowledgements}

LT was funded by a FRIA-FNRS (Fonds National de la Recherche Scientifique) grant. GL is a FRSFNRS research associate. This work is supported by the FNRS project PDR/OL T.0084.18. The sampling expedition was supported by the Fonds Leopold III pour l'Exploration et la Conservation de la Nature.

\section{References}

BAillon S., HAmel J.F. \& Mercier A. (2014). Diversity, distribution and nature of faunal associations with deep-sea pennatulacean corals in the Northwest Atlantic. PloS ONE 9 (11): e111519. https://doi.org/10.1371/journal.pone.0111519

Bearhop S., AdAms C.E., WAldron S., Fuller R.A. \& Macleod H. (2004). Determining trophic niche width: a novel approach using stable isotope analysis. Journal of Animal Ecology 73 (5): 10071012. https://doi.org/10.1111/j.0021-8790.2004.00861.x

Becker E.L., Cordes E.E., Macko S.A., Lee R.W. \& Fisher C.R. (2013). Using stable isotope compositions of animal tissues to infer trophic interactions in Gulf of Mexico lower slope seep communities. PloS ONE 8 (12): e74459. https://doi.org/10.1371/journal.pone.0074459

Bo M., Rouse G., MARTin D. \& BAVESTREllo G. (2014). A myzostomid endoparasitic in black corals. Coral Reefs 33 (1): 273-273.

Boag B., Neilson R., Robinson D., Scrimgeour C.M. \& Handley L.L. (1998). Wild rabbit host and some parasites show trophic-level relationships for $\delta 13 \mathrm{C}$ and $\delta 15 \mathrm{~N}$ : a first report. Isotopes in Environmental and Health Studies 34 (1-2): 81-85. https://doi.org/10.1080/10256019708036335 
TERRANA L. et al., Trophic relationships between black corals and their symbionts

BOLAND R.C. \& PARRISH F.A. (2005). A description of fish assemblages in the black coral beds off Lahaina, Maui, Hawai'i. Pacific Science 59: 411-420. https://doi.org/10.1353/psc.2005.0032

BRUCE A.J. (1978). A report on a collection of pontoniine shrimps from Madagascar and adjacent seas. Zoological Journal of the Linnean Society 62: 205-290.

https://doi.org/10.1111/j.1096-3642.1978.tb01039.x

BRUCE A.J. (2005). Pontoniine shrimps from the 2003 NORFANZ Expedition, 10 May-16 June (Crustacea: Decapoda:Palaemonidae). Zootaxa 981: 1-20. https://doi.org/10.11646/zootaxa.981.1.1

Buhl-Mortensen L. \& MorTensen P.B. (2004). Symbiosis in deep-water corals. Symbiosis 37: 33-61

Caulier G., Lepoint G., VAn Nedervelde F. \& Eeckhaut I. (2014). The diet of the Harlequin crab Lissocarcinus orbicularis, an obligate symbiont of sea cucumbers (holothuroids) belonging to the genera Thelenota, Bohadschia and Holothuria. Symbiosis 62: 91-99.

https://doi.org/10.1007/s13199-014-0274-2

CRiales M.M. (1980). Commensal caridean shrimps of Octocorallia and Antipatharia in Curaçao and Bonaire with description of a new species of Neopontonides. Studies on the Fauna of Curaçao and other Caribbean Islands 61 (1): 68-85.

DARIMONT C.T., PAqueT P.C. \& REIMCHEN T.E. (2009). Landscape heterogeneity and marine subsidy generate extensive intrapopulation niche diversity in a large terrestrial vertebrate. Journal of Animal Ecology 78 (1): 126-133. https://doi.org/10.1111/j.1365-2656.2008.01473.x

DAVIS W.P. \& COHEN D.M. (1968). A gobiid fish and a palaemonid shrimp living on an antipatharian sea whip in the tropical pacific. Bulletin of Marine Science 18 (4): 749-761.

DENIRO M.J. \& EPSTEIN S. (1981). Influence of diet on the distribution of nitrogen isotopes in animals. Geochimica et Cosmochimica Acta 45: 341-351. https://doi.org/10.1016/0016-7037(81)90244-1

De Ridder C. \& Holthuis L.B. (1979). Pontonides sympathes, a new species of commensal shrimp (Crustacea, Decapoda, Pontoniinae) from Antipatharia in the Galapagos Islands. Zoologische Mededelingen 54 (7): 101-110.

Deudero S., Pinnegar J.K. \& Polunin N.V. (2002). Insights into fish host-parasite trophic relationships revealed by stable isotope analysis. Diseases of Aquatic Organisms 52 (1): 77-86. https://doi.org/10.3354/dao052077

Doucett R.R., Giberson D.J. \& POWER G. (1999). Parasitic association of Nanocladius (Diptera:Chironomidae) and Pteronarcys biloba (Plecoptera:Pteronarcyidae): insights from stableisotope analysis. Journal of the North American Benthological Society 18: 514-523.

EECKHAUT I. \& LANTERBECQ D. (2005). Myzostomida: a review of the phylogeny and ultrastructure. Hydrobiologia 535 (1): 253-275. https://doi.org/10.1007/s10750-004-5636-y

Fleming N.E.C., Harrod C., Griffin D.C., Newton J. \& Houghton J.D.R (2014). Scyphozoan jellyfish provide short-term reproductive habitat for hyperiid amphipods in a temperate near-shore environment. Marine Ecology Progress Series 510: 229-240. https://doi.org/10.3354/meps 10896

Frédérich B., Michel L.N., Zaeytydt E., Bolaya R.L., Lavitra T., Parmentier E. \& Lepoint G. (2017) Comparative feeding ecology of cardinalfishes (Apogonidae) at Toliara Reef, Madagascar. Zoological Studies 56: 10. https://doi.org/10.6620/ZS.2017.56-10

Goenaga C. (1977). Two New Species of Stichopathes (Zoantharia; Antipatharia) with Observations on Aspects of Their Biology. Unpublished MS Thesis, University of Puerto Rico, Puerto Rico.

HERLER J. (2007). Microhabitats and ecomorphology of coral- and coral rock-associated gobiid fish (Teleostei: Gobiidae) in the northern Red Sea. Marine Ecology 28: 82-94.

https://doi.org/10.1111/j.1439-0485.2007.00165.x 
Iken K., Brey T., Wand U., Voigt J. \& Junghans P. (2001). Food web structure of the benthic community at the Porcupine Abyssal Plain (NE Atlantic): a stable isotope analysis. Progress in Oceanography 50 (1-4): 383-405. https://doi.org/10.1016/s0079-6611(01)00062-3

Jackson A.L., Inger R., Parnell A.C. \& Bearhop S. (2011). Comparing isotopic niche widths among and within communities: SIBER - Stable Isotope Bayesian Ellipses. Journal of Animal Ecology 3: 595-602. https://doi.org/10.1111/j.1365-2656.2011.01806.x

KiRKEndAle L. \& Messing C.G. (2003). An annotated checklist and key to the Crinoidea of Guam and the Commonwealth of the Northern Marianas Islands. Micronesica 3536: 523-546.

LARSON H. (1985). A revision of the gobiid genus Bryaninops (Pisces), with a description of six new species. Beagle, Records of the Museums and Art Galleries of the Northern Territory 2 (1): 57-93. Available from https://biodiversitylibrary.org/page/55710181 [accessed 24 Oct. 2019].

Love M.S., YoKlavich M.M., Black B.A. \& Andrews A.H. (2007). Age of black coral (Antipathes dendrochristos) colonies, with notes on associated invertebrate species. Bulletin of Marine Science 80 (2): 391-399.

MARIN I. (2007). The coral-associated shrimp genus Pontonides (Caridea, Palaemonidae, Pontoniinae) in Nhatrang Bay, Vietnam, with description of two new species. Zootaxa 1635: 1-21.

https://doi.org/10.5281/zenodo.179514

McCutchan J.H., LeWIS W.M., Kendall C. \& MCGRATH C.C. (2003). Variation in trophic shift for stable isotope ratios of carbon, nitrogen and sulfur. Oikos 102: 378-390.

https://doi.org/10.1034/j.1600-0706.2003.12098.x

MOLODTSOVA T.N. \& BUDAEVA N. (2007). Modifications of corallum morphology in black corals as an effect of associated fauna. Bulletin of Marine Science 81: 469-479.

Munday P.L., Pierce S.J., Jones G.P. \& LARSON H.K. (2002). Habitat use, social organization and reproductive biology of the seawhip goby, Bryaninops yongei. Marine Freshwater Research 53: 769775. https://doi.org/10.1071/mf01205

NEILSON R. \& BROWN D.J. (1999). Feeding on different host plants alters the natural abundances of $\delta^{13} \mathrm{C}$ and $\delta^{15} \mathrm{~N}$ in Longidoridae (Nemata). Journal of Nematology 31 (1): 20.

PARMENTIER E. \& DAS K. (2004). Commensal vs. parasitic relationship between Carapini fish and their hosts: some further insight through $\delta 13 \mathrm{C}$ and $\delta 15 \mathrm{~N}$ measurements. Journal of Experimental Marine Biology and Ecology 310 (1): 47-58. https://doi.org/10.1016/j.jembe.2004.03.019

PARMENTIER E. \& Michel L. (2013). Boundary lines in symbiosis forms. Symbiosis 60: 1-5. https://doi.org/10.1007/s13199-013-0236-0

Parnell A., Inger R., BeArhop S. \& JACKSON A.L. (2008). SIAR: Stable isotope analysis in R. Available from https://rdrr.io/cran/siar/ [accessed 24 Oct. 2019].

PHILLIPS D.L. \& KoCH P.L. (2002). Incorporating concentration dependence in stable isotope mixing models. Oecologia 130 (1): 114-125.

Phillips D.L., Inger R., Bearhop S., Jackson A.L., Moore J.W., Parnell A.C., Semmens B.X. \& WARD E.J. (2014). Best practices for use of stable isotope mixing models in food-web studies. Canadian Journal of Zoology 92 (10): 823-835. https://doi.org/10.1139/cjz-2014-0127

PinNegar J.K., CAMPBell N. \& Polunin N.V.C. (2001). Unusual stable isotope fractionation patterns observed for fish host-parasite trophic relationships. Journal of Fish Biology 59 (3): 494-503. https://doi.org/10.1111/j.1095-8649.2001.tb02355.x

Post D.M. (2002). Using stable isotope to estimate trophic position: models, methods, and assumptions. Ecology 83: 703-718. https://doi.org/10.2307/3071875 
TERRANA L. et al., Trophic relationships between black corals and their symbionts

Power M. \& KleIn G.M. (2004). Fish host-cestode parasite stable isotope enrichment patterns in marine, estuarine and freshwater fishes from northern Canada. Isotopes in Environmental and Health Studies 40 (4): 257-266. https://doi.org/10.1080/10256010410001678062

R Development Core TeAm. (2015). R: A Language and Environment for Statistical Computing. Vienna, Austria. Available from http://www.R-project.org [accessed 24 Oct. 2019].

RAFFEL T.R., MARTIN L.B. \& ROHR J.R. (2008). Parasites as predators: unifying natural enemy ecology. Trends in Ecology \& Evolution 23 (11): 610-618. https://doi.org/10.1016/j.tree.2008.06.015

RichouX N.B. \& NDHLOvU R.T. (2015). Temporal variability in the isotopic niches of rocky shore grazers and suspension feeders. Marine Ecology 36 (4): 1045-1059. https://doi.org/10.1111/maec.12200

Semmens B.X., Ward E.J., MoOre J.W., DARIMont C.T. (2009). Quantifying inter- and intrapopulation niche variability using hierarchical Bayesian stable isotope mixing models. PLoS ONE 4: e6187. https://doi.org/10.1371/journal.pone.0006187

SiH J. \& CHOUW J. (2009). Fish and whips: Use of gorgonians as a habitat by the large whipcoral goby, Bryaninops amplus (Larson). Raffles Bulletin of Zoology 22: 145-157.

Soule D.F. \& Soule J.D. (1972). Ancestrulae and body wall morphogenesis of some Hawaiian and eastern Pacific Smittinidae (Bryozoa). Transactions of the American Microscopical Society 91: 251260. https://doi.org/10.2307/3224873

SYVÄRANTA J., LENSU A., MARKOMÄKI T.J., OKSANEN S. \& JONES R.I. (2013). An empirical evaluation of the utility of convex hull and standard ellipse areas for assessing population niche widths from stable isotope data. PLoS ONE 8: 1-8. https://doi.org/10.1371/journal.pone.0056094

TERRANA L. \& EECKhaUt I. (2017). Taxonomic description and 3D modelling of a new species of myzostomid (Annelida, Myzostomida) associated with black corals from Madagascar. Zootaxa 4244 (2):277-295. https://doi.org/10.11646/zootaxa.4244.2.9

Terrana L., Caulier G., Todinanahary G., Lepoint G. \& Eeckhaut I. (2016). Characteristics of the infestation of Seriatopora corals by the coral gall crab Hapalocarcinus marsupialis Stimpson, 1859 on the great reef of Toliara, Madagascar. Symbiosis 69 (2): 113-122.

https://doi.org/10.1007\%2Fs13199-016-0391-1

Vega R., Vega R. \& LuQue A.A. (2002). Coralliophila kaofitorum, a new species (Gastropoda: Coralliophilidae) from the Canary Islands living on Antipathes wollastoni (Cnidaria: Anthozoa: Antipatharia). Nautilus 116: 50-55.

WAGNer D., Luck D.G. \& ToONEN R.J. (2012). The biology and ecology of black corals (Cnidaria: Anthozoa: Hexacorallia: Antipatharia). Advances in Marine Biology 63: 67-132.

https://doi.org/10.1016/b978-0-12-394282-1.00002-8

WiRTZ P. \& D'UdEKEM-D'Acoz C. (2001). Decapoda from Antipatharia, Gorgonaria and Bivalvia at the Cape Verde Islands. Helgoland Marine Research 55: 112-115. https://doi.org/10.1007/s101520100073

Manuscript received: 18 November 2018

Manuscript accepted: 7 October 2019

Published on: 28 November 2019

Branch editor: Steven Degraer 